\title{
OS SERTÕES DO GRUPO OFICINA: ANTES DE TUDO UM TEAT(R)O POLÍTICO
}

Patrícia Mc Quade

Mestre em Letras: Estudos Literários - UFMG

\begin{abstract}
RESUMO
O presente ensaio desenvolve uma reflexão sobre a leitura que José Celso Martinez Corrêa fez da personagem Euclides da Cunha e de sua obra Os sertões como uma expressão de ato político. A peça é dividida em cinco partes: A Terra, O Homem I, O Homem II, A Lutas I e A Luta II - cada uma sendo apresentada em um dia e somando um total de quase $30 \mathrm{~h}$ de apresentação espetacular. O texto dramatúrgico/espetacular de José Celso é considerado neste estudo como uma leitura/concepção de Os sertões de Euclides da Cunha e, como tal, reproduz todas as suas contradições e particularidades teatrais do grupo ao longo de sua trajetória de mais de 50 anos de atuação.
\end{abstract}

\section{PALAVRAS-CHAVE}

Teatro Oficina, José Celso Martinez Corrêa, política, arte, identidade cultural

\begin{abstract}
O teatro não sobreviverá um dia que seja à vida dum homem. À medida que nasce, terá de morrer. Os únicos vestígios que ele poderá deixar ficarão gravados no ser humano manifestando-se por uma mudança psicológica. Se o fim das outras artes é criar obras, o do teatro será mudar diretamente o homem: o Teatro não é uma Arte, mas uma Ciência da Vida.
\end{abstract}

Alejandro Jodorowsky ${ }^{1}$

José Celso Martinez Corrêa teatralizou Os sertões de Euclides da Cunha. O livro é dividido em três partes: “A Terra”, “O Homem” e “A Luta”, que no Teat(r)o Oficina

\footnotetext{
${ }^{1}$ Alejandro Jodorowsky é chileno, líder e fundador de um movimento teatral conhecido como Movimento Pánico (em alusão ao deus Pan, da mitologia grega, que se manifesta através de três elementos básicos: terror, humor e simultaneidade). Fragmento de um de seus numerosos manifestos, Vers l'éphémère panique, escrito em outubro de 1965.
} 
desdobraram-se em cinco: A Terra, O Homem I: do pré-homem à revolta; O Homem II: da revolta ao trans-homem; A Luta I: 1a, 2a e 3a expedições + Rua do Ouvidor e A Luta II: O des-massacre.

A partir da importância das obras de Euclides da Cunha para a literatura e do Grupo Oficina para a historiografia do teatro brasileiro, o presente ensaio tem como objetivo pincelar algumas características da materialidade espetacular de Os sertões do Grupo Oficina, sem desconsiderar a obra inspiradora e monumental de Euclides da Cunha que é, por sua vez, tomada apenas como pano de fundo para a análise do espetáculo. O Teatro Oficina ${ }^{2}$ possui um vasto e fértil terreno de produções artísticas, culturais e de inúmeras mobilizações políticas, tendo em vista o monumento artístico complexo que são as experiências, as vivências teatrais e ações políticas de José Celso e seu grupo ao longo dos últimos 50 anos de atuação. E, ultrapassando os limites da materialidade do espaço físico e da arte espetacular, o Oficina é também aqui contemplado como patrimônio imaterial da cultura brasileira, primeiro porque é uma referência para quem se ocupa do teatro e de suas múltiplas manifestações e, segundo, porque é espaço de resistência cultural e social que visa à democratização da cultura, tendo como política social o acesso de todos as produções de arte vigentes em seu país.

Proponho aqui fazer uma reflexão da peça Os sertões sob o olhar da história do Teatro Oficina, o seu espírito revolucionário, subversivo e de resistência contra qualquer forma de autoritarismo, seja ela política, social ou econômica. A luta de resistência que foi travada por esse grupo na época da montagem dessa peça em especial foi contra a implantação de um Shopping Center no bairro Bixiga, exatamente no quarteirão em que o Teatro está localizado. Esse projeto, de “estratégias mercadológicas e urbanicidas", ${ }^{3}$ como acusa José Celso, foi idealizado pelas empresas Sílvio Santos e acusado pelo Grupo Oficina como um empreendimento que defende um sistema autoritário de base estritamente econômica, baseado na legitimidade dos bens privados e na irrestrita liberdade de comércio, com o principal objetivo de adquirir lucros financeiros, além de trazer algumas consequências veladas para a comunidade do bairro: a exclusão social com uma maior elitização da sociedade do bairro e, ainda, objetivos

\footnotetext{
${ }^{2}$ Localizado à Rua Jaceguai, 520 - bairro Bixiga, São Paulo - SP. O Teatro Oficina conquistou seu tombamento com o apoio do órgão Condephaat (Conselho de Defesa do Patrimônio Histórico, Arqueológico, Artístico e Turístico) em 1982. Foi projetado pela arquiteta Lina Bo Bardi, italiana radicada brasileira, que o transformou em um teatro-pista, com parede de vidro, teto (retrátil) móvel. Sua arquitetura foi vencedora da Bienal de Praga em 1999.

${ }^{3}$ Disponível em: <http://www2.uol.com.br/teatroficina/novosite/officina/arteafavor.html>.
} 
que visam à especulação imobiliária e comercial, levando à acumulação de riquezas nas mãos de uma minoria privilegiada, fato que não é novidade em nossa triste história de "brava gente brasileira”.

Em contrapartida, o Grupo Oficina anseia e luta pela democratização da cultura e da educação ao propor a construção de um Teatro Estádio e de uma Universidade Antropofágica, projetados e idealizados em parceria com os arquitetos Lina Bo Bardi, Edson Elito e Paulo Mendes da Rocha. Esse projeto tem o objetivo urbanístico de transformar o teatro em um espaço público de passagem física, que vai desde a Rua Jaceguai, endereço atual, com abertura para a Rua Japurá, atual estacionamento de furgões do "Baú da Felicidade”. O conjunto arquitetônico visa também à construção de outros prédios destinados à Universidade Antropofágica, que irão auxiliar na produção sociocultural da Associação Uzyna Uzona ${ }^{4}$ e de pesquisas artísticas: um embaixo do Minhocão e outros dois na rua paralela à Jaceguai. José Celso, defendendo o que denomina de projeto Ágora - alusão à praça principal na constituição da polis, a cidade grega da Antiguidade clássica -, escreve em seu manifesto:

Não acreditamos na promessa de revitalização deste bairro com a construção de mega-empreendimentos que o transformarão num bairro utilitário, sem que os seus problemas sejam tratados. Queremos combater os efeitos da especulação imobiliária que aqui se instalou há mais de vinte anos, com a fertilização desta terra através de produções artísticas e trabalhos sociais. $^{5}$

Esse projeto cultural do Grupo Oficina está hoje cada vez mais perto de enfim concretizar-se. No final de janeiro deste ano (2010) o Grupo Silvio Santos negocia a venda do terreno anexo ao Teatro Oficina no bairro Bixiga e abre a possibilidade de encerrar de uma vez por todas esse embate travado entre a cultura e o poder capitalista. Provavelmente, a compradora do terreno é a Funart (Fundação Nacional das Artes), ligada diretamente ao Ministério da Cultura. Ficamos agora na expectativa de novas notícias sobre a possibilidade da construção desse mega empreendimento cultural que irá localizar o Brasil dentre as principais produções cênicas do mundo.

A obra Os sertões do Grupo Oficina é um marco no teatro brasileiro. O seu projeto artístico-ideológico ultrapassa os limites da própria arte e penetra com profusão

\footnotetext{
${ }^{4}$ Além de uma intensa produção de peças teatrais, o grupo mantém pequenas oficinas que oferecem à comunidade ensinamentos culturais que ajudam a formação de uma autoestima individual e uma identidade cultural coletiva a crianças e jovens dos arredores do bairro, como: dança, capoeira, atividades cênicas, canto, etc.

${ }^{5}$ Disponível em: <http://www2.uol.com.br/teatroficina/velhosite/manifesto.htm>.
} 
na vida de quem se atreve a coparticipar dessa contagiante festa a Dioniso. Além disso, foi uma elegante e acertada resposta à emboscada mercadológica que o grupo Sílvio Santos tentou, em vão, arquitetar contra o teatro do bairro Bixiga, ${ }^{6}$ que sofre processo de apagamento de sua memória histórico-social ao ser rebatizado de Bela Vista. José Celso, em suas “Conclusões finais de um início”, declara:

\begin{abstract}
Aprendi mais que em toda minha vida nesses quase 6 anos em que decidimos montar Os sertões no Teatro Oficina, como transporte, metáfora e uma grande aposta no poder da Arte do Teatro como libertação deste Cerco de 25 anos que anunciava um possível Massacre do Teatro Oficina pelo Shopping do Grupo Sílvio Santos. E acabou sendo mais que isso porque, antes de tudo, o livro de Euclides é um Imenso Poema clamando por ser cantado e dançado e em si foi construindo seu território físico anímico. ${ }^{7}$
\end{abstract}

Os sertões, do grupo Oficina Uzyna Uzona, está sendo aqui considerado como um ponto de vista sobre um acontecimento, um olhar, um ângulo de visão sobre a História. E precisamente por esse deslocamento da relação entre o olhar e o objeto olhado é que ocorre a construção de outro texto onde tem lugar à representação. Esse deslocamento provoca uma abertura que amplia e problematiza o entendimento daquilo que denominamos “realidade” - a que é exposta em Os sertões de Euclides da Cunha -, e ao subvertê-lo podemos expandi-lo a outros possíveis reconhecimentos dessa mesma “realidade” - a concepção teatral de Os sertões de José Celso Martinez Corrêa - através de um novo olhar que se estabelece: a teatralidade.

Em uma entrevista ao Jornal da Bahia, na última turnê realizada pelo grupo com a peça Os sertões em 2007, José Celso diz que os cinco espetáculos não são apenas uma atualização histórica no tempo e espaço da obra centenária de Euclides da Cunha, mas antes uma atuação na vida através da teatralização da própria realidade:

É mais que atualização para o palco, que quase não usamos. Atuamos numa Pista, na rua, vivendo nossa epopeia, nossa luta para não sermos capturados, massacrados pela atualidade do rebanho neoliberal. Como os Conselheristas, querendo construir Açudes, Igrejas e Cemitérios, nós por exemplo, que queremos que a estátua de Antonio Conselheiro

${ }^{6}$ O Bixiga é um dos mais tradicionais bairros da cidade de São Paulo, embora na divisão administrativa da cidade ele não exista oficialmente. Está localizado entre as ruas Rui Barbosa, Nove de Julho e a dos Franceses, no distrito de Bela Vista. Foi formado por imigrantes italianos e ganhou importância histórica e turística na capital paulista. Com o intuito de afastar o sentido pejorativo do apelido dado ao bairro (bexiga: nome popular para varíola), seus moradores passaram a mudar a grafia de Bexiga para Bixiga. No Bixiga fica localizada a sede da Escola de Samba Vai-Vai.

${ }^{7}$ Disponível em: <http://teatroficina.uol.com.br/novosite/sertoes/aluta2/pagina/inicio.html>. 
seja reposta em frente ao Teatro Castro Alves, que se crie um Pulmão, um Açude Cultural no deserto Urbano do centro de São Paulo no Bexiga. A peça é o transporte para nossa vida aqui agora. No contacto direto com a Multidão que iremos encontrar, por exemplo, em Salvador no terreiro do Orixá Carlinhos Brown vamos estar atualizando 'Os Sertões'. O teatro é sempre aqui agora, atual e virtual também, através da Internet, dos DVDs. Cada espetáculo é único e é o Eterno Presente. Não posso imaginar um teatro que não seja uma incorporação de corpo presente no passado-futuro-presente que é estar em círculo, em ovo com uma multidão viva, com tambores, música, dança, improvisações, repentes, batalhas, mantras, poemas, situações e sobretudo uma INTERPRETACÃO DO BRASIL, DO MUNDO, DAS GENTES QUE NÃO SEJA, CHAPA BRANCA, NÃO REBANHO, mas "ROCHA VIVA" como cantou o Poeta Euclides. ${ }^{8}$

Recriação, re-invenção, apropriação? Como definir a peça Os sertões? Como analisar a complexa geografia euclidiana do Ser-tão brasileiro que o Grupo Te-at(r)o Oficina contracenou entre os anos de 2002 e 2007? Como o grupo apreende e transforma em totem ${ }^{9}$ o espectro neocapitalista do grupo Sílvio Santos, que vem ameaçando o Teatro Oficina por mais de 25 anos? A partir desses questionamentos cheguei a uma definição particular dessa obra teatral: Os sertões do Oficina é antes de tudo uma "leitura-concepção" da obra literária de Euclides da Cunha.

Entendo aqui "leitura-concepção" como um conceito: a leitura como ato de vivenciar de forma particular uma obra, trazê-la para dentro de si, ressignificando-a. A concepção como ato de fazer nascer o intertexto de maneira performativa, trazendo a arte-obra, sua trama-textura, como presentificação. ${ }^{10}$ Essa lei de reciprocidade entre leitura e concepção interfere no olhar que se tem sobre o livro; modela não só o olhar do espectador perante o ato cênico, como também o do leitor diante do texto original e o seu papel sociopolítico na sociedade. Em outras palavras, o modo de transmissão textocena está intrínseco a um desdobramento da recepção da obra primeira, transforma o juízo que o leitor-espectador tem do livro de Euclides e leva-o a ressignificar a obra dentro do seu contexto de cocidadão brasileiro.

${ }^{8}$ Entrevista concedida a Marcos Uzel, do Correio da Bahia: 14 de setembro de 2007. Disponível em: <http://teatroficina.uol.com.br/posts/86>. (grifos do autor)

${ }^{9}$ Os atores do Oficina falam constantemente em transformar o tabu em totem. Referência ao "Manifesto Antropófago" de Oswald de Andrade: “Tínhamos a justiça codificação da vingança. A ciência codificação da Magia. Antropofagia. A transformação permanente do Tabu em Totem.” (ANDRADE. Manifesto Antropofágico, p. 355.) Oswald, por sua vez, recupera ideias expostas no livro de Freud: Totem e Tabu.

${ }^{10}$ Ato pelo qual um objeto se torna presente em forma de imagem inserida em um tempo vivido, sentida como parte de um tempo presente, integrada como tal na memória coletiva de um povo. 
Numa entrevista publicada na revista Folhetim, José Celso afirma:

O teatro é essencialmente da polis, da comunicação com a cidade, e com o outro, com o mundo, mas o teatro só vai retomar o poder dele se se compreender como teatro político, não político-partidário, mas como realidade política. A existência do teatro hoje depende de uma consistência política enorme. ${ }^{11}$

A partir de um olhar panorâmico, entendo a teatralidade d'Os sertões como a essência do teatro tangível no palco, onde se encontram basicamente a linguagem verbal, a icônica e suas materialidades, o espaço cênico, a representação do real e a sua presentificação, a dramaticidade do texto e da encenação, a imprevisibilidade e a improvisação, a efemeridade, a polifonia sensorial e sensual, o contato ator/espectador e a tridimensionalidade espacial de sua mensagem. No entanto, ao analisar a obra Os sertões, creio que mais um item deva ser acrescentado: a teatralidade, nessa obra, é antes de tudo um meio de materializar o impossível, uma forma política e libidinosa de fazer arte de contestação, sem abrir mão do prazer que a própria criação artística proporciona a todos que participem dela e por ela.

Ao distender o limite do conceito teatralidade, o Teatro Oficina propõe dentro do nome teat(r)o o te-ato. Em uma entrevista a José Arrabal, em fevereiro de 1980, José Celso explicita o te-ato:

É isso! Te-ato é uma atuação exatamente de desmascaramento do teatro das relações sociais. Desmascaramento do teatro que existe a partir das relações sociais, de filho com a mãe, de pai e filho, patrão e empregado etc. Nesse desmascaramento, o te-ato provoca uma nova consciência física da existência. Não é uma experiência intelectual, mas sim uma experiência com o corpo que passa por uma ação real. É uma coisa mais próxima de Artaud, ou então de macumba, ou de dança primitiva. É alguma coisa que provoca e tem a pretensão de provocar uma mudança física. É através da ação que você chega a mudar alguma coisa. E no te-ato há isso, essa crença de que o homem é que muda o homem. ${ }^{12}$

Esse trocadilho-conceito traz em si a ideologia do grupo, principalmente em dois sentidos anárquicos que estruturam toda a companhia dentro de uma visão política.

O primeiro seria o teatro que teatraliza os artistas contemporâneos. Neste Ato, ele consequentemente reforça, no seu agora, a função social dele mesmo, que consiste

\footnotetext{
${ }^{11}$ REVISTA FOLHETIM, p. 125.

${ }^{12}$ MARTINEZ CORRÊA. Primeiro Ato: cadernos, depoimentos, entrevistas (1958-1974), p. 321.
} 
no desejo de despertar tanto nos atores quanto nos espectadores uma consciência política, levando-os a construir um corpo social consistente, que atue criticamente em seu contexto sociocultural, transformando e ressignificando a realidade em que vivem. Essa transformação não se pretende intelectual, tampouco se quer didática no sentido de educar o público a "pensar politicamente". Ela se quer orgânica, visceral, onde o homem descubra dentro de si mesmo todas as potencialidades do seu poder de transformação e descubra, por sua conta e risco, como fazer uso delas. José Celso, em uma entrevista à revista Folhetim, afirma:

(...) o meu desejo é botar o teatro no mundo, plugado, nas mídias, envolvido com as lutas, paixões urbanas, com as lutas sociais, com tudo. E trazer o que ele tem de mais importante, que é a questão do político, a questão do poder. Que poder tem o ser humano para não se submeter totalmente à imposição da máquina, seja ela qual for, a máquina do capitalismo, a máquina da tecnologia, do que é dominante? Que poder ele tem de contracenar com isso e com o meio, e não ser comido por ele? ${ }^{13}$

O segundo sentido seria o de experimentar todas as possibilidades humanas e de recursos cênicos que o teatro poderia explorar para potencializar essa voz intrincada da anarquia. Para tanto, José Celso acredita no trabalho da coletividade que reúne um conjunto de profissionais solidários e unificados por um mesmo propósito comunicativo - a equipe de teatro - e um outro conjunto de indivíduos igualmente solidários e empenhados numa vibração comum que os percorre e faz vibrar a cena - o público.

O teatro em si é anárquico, afirma José Celso, o teatro trabalha em forma de conselho, em equipe, eu trabalho muito bem coletivamente, eu gosto de muita gente, gente de vídeo, figurino, de cenário, de luz, todo mundo dando palpite em tudo. Orgia. ${ }^{14}$

Com a quebra do limite entre palco e plateia que o teatro (re)descobriu, passou a haver um contato mais físico, mais humano entre ator e espectador. ${ }^{15}$ Esse é um dispositivo cênico altamente trabalhado pelo Grupo Oficina, que busca um contato mais verdadeiro com seu público, o prazer de um intercâmbio real, o contato físico, o assédio, a provocação, o encontro e a divergência dos olhares entre atores e espectadores (ambos

\footnotetext{
${ }^{13}$ REVISTA FOLHETIM, p. 131.

${ }^{14}$ REVISTA FOLHETIM, p. 133.

${ }^{15}$ Podemos lembrar aqui de alguns precursores que lutaram para que a ruptura da chamada quarta parede realmente acontecesse: Piscator, Brecht, Artaud, Grotowski, Living Theatre, Augusto Boal, o próprio Teatro Oficina, entre outros.
} 
os atuadores, no caso). Esse contato deve ter a sua natureza física e metafísica a fim de alcançar uma transformação corpórea, uma experiência comprometida com a matéria, com as sensações libidinosas despertadas nos corpos de quem se entrega ao espetáculo.

A estrutura do Teatro Oficina possibilita esse happening, ${ }^{16}$ de forma a fazer da tridimensionalidade do teatro uma tridimensionalidade do real, mais sensitiva, criando um envolvimento espacial total ao redor do espectador. ${ }^{17} \mathrm{O}$ palco longitudinal interliga a entrada aos bastidores do teatro e a buracos na parede dos fundos. ${ }^{18}$ Arquibancadas dispostas ao longo dessa passarela possuem três andares, onde espectadores e atores atuam. Um corredor subterrâneo foi aberto para servir de trincheiras construídas pelos sertanejos na época da guerra. Alçapões ao longo do palco se abrem e deslindam inúmeras surpresas desse subterrâneo nos espetáculos. Tudo se revela - camarins, escritório do diretor, maquinário cênico, contrarregras, telões, músicos. Seria o corpo sem órgãos aplicado à arquitetura do teatro e à ideologia política do grupo. O palco enquanto corpo dessacralizado, destituído de sistemas, de hierarquias institucionalizadas, destituído de órgãos. Uma árvore tem suas raízes arraigadas dentro do teatro, porém sua copa se expande para fora dele (seria um signo libertário?). As paredes do teatro não impediram seu crescimento, pelo contrário, o projeto de construção respeitou esse espaço, permitiu-se no deslimite de sua evolução vegetal.

\footnotetext{
16 "Atividade proposta e realizada pelos artistas e participantes, utilizando o acaso, o imprevisto e o aleatório, sem vontade de imitar uma ação exterior, de contar uma história, de produzir um significado, usando todas as artes e técnicas imagináveis quanto à realidade circundante.” (PAVIS. A análise dos espetáculos, p. 191.)

${ }^{17}$ A arquitetura do Teatro Oficina possibilita esse contato ator/espectador de forma bem intensa. O prédio foi projetado pela arquiteta Lina Bo Bardi, italiana radicada brasileira que participou das criações teatrais do grupo desde 1969 como cenógrafa. Depois de sua anistia, José Celso conquista o tombamento do prédio pela Condephaat em 1982; e Lina Bo Bardi transforma o interior do edifício em um teatro-pista, com parede de vidro, teto (retratil)móvel, arquibancadas laterais, palco para os músicos, fonte etc. Essa arquitetura foi vencedora da Bienal de Praga em 1999. Lina Bo Bardi também projetou dois outros edifícios emblemáticos na cidade de São Paulo: o prédio do MASP - Museu de Arte de São Paulo e o SESC Fábrica da Pompeia; ambos os projetos arrojados, que parecem desafiar as leis da gravidade, pois possuem vãos livres no andar térreo e passarelas que interligam os andares superiores. $\mathrm{O}$ Teatro Oficina, denominado a partir de seu tombamento de "Terreiro Eletrônico", conquistou o patrocínio da Petrobras e a construção, em 2007, da estrutura móvel do Teatro/réplica Oficina para a realização de turnês em todo o Brasil, dada à importância da arquitetura como parte fundamental de seu repertório.

18 "Há anos fazemos estes buracos, o vizinho [GSS] tapa, nós fazemos de novo. A História dos últimos 26 anos do Oficina está toda neste Buraco. Tudo filmado. Fotografado. Enfeitiçado. Sagrado. Até a queda de todos os muros que é este muro. Beco sem saída. Tudo que entra por uma boca tem de sair por outra como no corpo humano." (Programa, A Terra. Teatro Oficina, 2006, p. 16.)
} 
Esse deslimite também se encontra no olhar amplo que se espera do espectador. $\mathrm{O}$ ato cênico se dá em um giro de $360^{\circ}$ : em qualquer ponto do teatro pode surgir um acontecimento ("norte, sul, leste, oeste, subterrâneo, céu”), ${ }^{19}$ é o imprevisível tomado como uma das essências da teatralidade empregada pelo Oficina para envolver o público e prender a sua atenção durante as longas horas de duração de suas peças. Em Os sertões, esse tempo pode chegar a aproximadamente 30h em sua totalidade.

A representação é outro dispositivo cênico peculiar nesse grupo. Desde a sua fundação, em 1958, muito se vem estudando e experimentando no tablado do Oficina entre as diversas teorias surgidas no século 20: desde o Método Naturalista de Stanislavski; a Teoria do Estranhamento de Brecht, com a proposta de Teatro Épico e as peças de tese; o Existencialismo de Sartre; o Laboratório Cênico de Grotowski com o foco no papel do ator e as possíveis reflexões sobre corpo e atuação cênica; o Teatro da Crueldade e o Teatro Ritual de Artaud; o Teatro do Oprimido de Augusto Boal ${ }^{20}$ e as muitas outras teorias contemporâneas investigadas e reinventadas pelo grupo como também a mistura de todas elas.

Compreende-se como representação teatral, parafraseando Armando Sérgio da Silva, ${ }^{21}$ a concretização mimética de uma suposta realidade apreendida a partir de similaridades no mundo real. O Teatro Oficina, em sua origem, procurava articular de forma constitutiva elementos da vida real, seus membros eram apegados ao texto dramático e se preocupavam em ser fiéis a ele e aos personagens ali descritos, procuravam seguir à risca o mestre Stanislavski. Depois de muitas experimentações cênicas e reflexões sobre os resultados obtidos, o grupo desenvolveu o poder da recriação do texto teatral que consiste em inventar, agrupar e interrelacionar ícones e símbolos de forma a gerar uma articulação sensitiva entre significado e significante, a partir da presentificação do ator, enquanto indivíduo, na construção da personagem, do acontecimento cênico e do texto se concretizando no palco com ligação direta ao contemporâneo, aos acontecimentos do aqui-agora.

Especificamente na peça Os sertões acontece uma nova obra a cada

\footnotetext{
${ }^{19}$ Frase recitada em coro por atores em A Terra, primeira parte da obra Os sertões.

${ }^{20}$ Ainda que possuíssem grandes divergências estéticas e políticas, os dois diretores (Augusto Boal e José Celso) sempre mantiveram um intercâmbio de experiências e apoio solidário nas dificuldades.

${ }^{21}$ SILVA. Oficina: do teatro ao te-ato.
} 
apresentação, um constante work in progress. ${ }^{22}$ As linguagens se multiplicam; utilizam o coro como voz coletiva; poemas e canções da cultura popular e erudita são recitados e/ou cantados; intertextualidade literal com a obra de Euclides da Cunha e de outros textos como, por exemplo, o "Manifesto Antropófago" de Oswald de Andrade; figuras famosas da história, da filosofia e da arte são transformadas em personagens ou são citadas frases de efeito de suas obras; inferências de acontecimentos em noticiários que geram algum tipo de polêmica; e clichês: muitos clichês! ${ }^{23}$ Em Os sertões temos elementos de melodrama, clown, pirotecnia, ópera, sangue falso, música hollywoodiana, nudez, samba, alegorias, agitação política, teatro nô, pantomima, orgia... Nenhum recurso humano ou cênico é desprezado desde que radicalize a teatralidade dessa epopeia. O excesso é a marca incontestável da arte de José Celso, que se autodenomina um barroco por convicção. Afirma que nada do que é humano lhe é desconhecido, ${ }^{24}$ e as experiências humanas passam por tudo: apelativos, clichês, erotismo, política. Vejamos um pequeno relato de uma cena contida em Os sertões, O Homem II, para melhor entender os deslimites dessa teatralidade e a re-criação da representação cênica do Teatro Oficina.

No meio da peça, as portas do teatro se abrem. Surge um cortejo festivo antecipado por Marechal Deodoro (Aury Porto) montado a cavalo. É o ato da proclamação da República que se dá enquanto é feita a montagem da nova bandeira do Brasil. No cortejo está, entre outras, Ana (Luciana Domschke), a esposa de Euclides da Cunha - mas pode ser também uma das irmãs do Conselheiro, Macha e também a própria Terra personificada. Na peça, tudo está o tempo todo em tensão, em estado de transfiguração. Uma atriz em uma mesma cena pode ser vista como diversas personagens. Essa leitura múltipla surge a partir das inferências que o espectador

\footnotetext{
${ }^{22}$ Conceito surgido a partir de James Joyce durante a escrita de seu romance Finnegans wake. A obra era publicada sob esse título (work in progress) numa revista Irlandesa à medida que sua escrita se progredia. (CAMPOS. Panaroma de finnegans wake.) Mais tarde esse conceito seria aproveitado na teoria da performance como a ideia de uma obra aberta, em constante estado de construção.

23 "Não copiamos os fatos, alteramos todas as datas, todas as genealogias, todos os desenhos do acontecimento, criamos nomes, personagens, só não afirmamos aquele velho clichê que qualquer semelhança é mera coincidência, porque não desfiguramos a alma, nem a cor, nem os sentimentos canudenses, nem os nossos, ou os euclidianos." (Programa da primeira parte da peça, A Terra, 2006, p. 49.)

${ }^{24}$ Entrevista cedida DW-WORLD no domingo, 23 de maio de 2004. "Humano sou: nada do que é humano me é estranho”. É a frase de Terêncio, cômico romano do século I. d.C. Disponível em: <http://www.dw-world.de/dw/article/01217894,00.html>.
} 
conseguir atribuir, ou seja, poderíamos dizer que o texto espetacular exige um "leitor modelo" que tenha a capacidade de desenvolver uma leitura com a riqueza de inferências que uma obra transversal exige.

Uma outra mulher, como as dançarinas dos programas de auditório, auxilia na montagem da bandeira e a inclusão da faixa branca. Ao fundo do teatro, no alto, uma senhora com aparência de muito velha, magra e pomposa (Vera Barreto Leite) representa textualmente a República e comanda a cena, ditando, sempre em francês, o lema de Auguste Comte: “L'amour pour principe...”; ao que é seguida por Ana: “O amor por princípio... O AMOR!”. O roteiro indica: “(Macha, uma das irmãs do Conselheiro, estica o bordado 'amor'. Aplausos calorosos. Assobios. Uma onda de amor-erótico envolve todos).” A república torna: “L'ordre pour base...” e outro personagem: “A ordem por base”. "Et le progrès pour but”. Outra personagem traduz: “E o progresso por fim.”

O Marechal discursa muito sério:

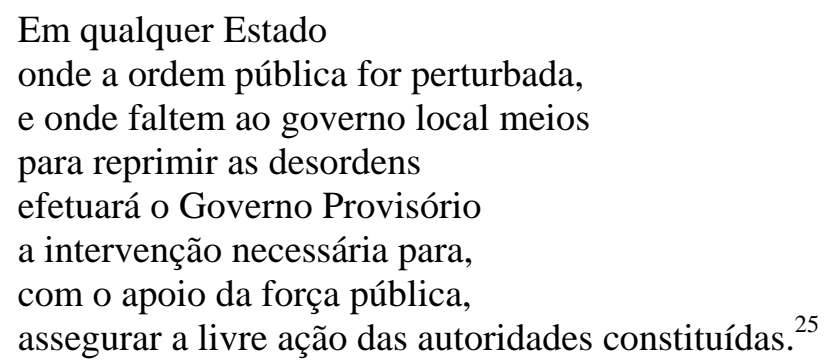

Enquanto isso, Ana está tão empolgada com a palavra Amor que começa a fazer uma manifestação a Eros, ou seja, uma pequena orgia com outros dois personagens em cima da bandeira. Deodoro fica indignado:

Ana da Cunha,

Olha Ela!

Dona Macha

Sinhá Cadela

Na Bandeira do Brasil!

O Amor não é um Canil

Para evitar indisciplina

Estirem esta faixa, opero eu esta faxina

Guilhotina!

Ordem e Progresso! ${ }^{26}$

\footnotetext{
${ }^{25}$ ROTEIRO: O HOMEM II.

${ }^{26}$ ROTEIRO: O HOMEM II.
} 
Sem descer do cavalo, o Marechal guilhotina a faixa com a espada, deixando apenas a inscrição “Ordem e Progresso”. Mais tarde, ver-se-á que a personagem Brasilina, mulher de Antônio Maciel, caminhará mendiga e enlouquecida pelo Brasil afora com a parte do bordado que traz a palavra "Amor” a tiracolo, escorrendo pelas pernas e acabará por pedir guarida em Canudos.

Mas antes, na continuação dessa passagem, todo o elenco vem à cena para cantar, em coro contagiante, a canção de Noel Rosa e Orestes Barbosa: “Positivismo”.

Essa linguagem híbrida do grupo é uma forma de fortalecer a identidade e a posição política e artística da mestiçagem brasileira, de herança antropófaga. A Associação Teat(r)o Oficina Uzyna Uzona, como tal, não teria jamais surgido e se desenvolvido sem esses elementos étnico, social e político híbridos fortalecidos em suas raízes. A coragem de José Celso em ultrapassar os limites, todos os limites do corpo e da mente, é o ingrediente-chave para o grupo ter se estabelecido, entre altos e baixos, por mais de 50 anos de atuação, como agente ativo das transformações sociais e artísticas brasileiras. Muitas foram as suas influências tanto nas artes cênicas quanto na música, poesia, cinema e artes plásticas. A peça $O$ rei da vela, de Oswald de Andrade, encenada pelo grupo em 1967, foi o estopim do movimento Tropicalista. Roda Viva, sucesso estrondoso em 1968, foi a estreia de Chico Buarque como dramaturgo. Parcerias musicais com vários compositores foram estabelecidas. Não há Teatro Oficina sem a exigência desesperada de atenção, de polêmicas sociais e judiciais, de confrontos com as instituições de poder, de estrondosos e surpreendentes sucessos onde permeiam também mazelas e derrotas, como as dificuldades enfrentadas durante a ditadura militar que resultou na prisão de vários integrantes do grupo e no exílio de José Celso em 1974 - sem contar com os obstáculos econômicos que o diretor superou para retomar o seu trabalho no Brasil e reconstruir o Teatro Oficina após a sua anistia em 1978. ${ }^{27}$

Esse corpo singular de atores, os que já fizeram parte da história do grupo e os que hoje atuam, essa voz coletiva que não perde a sua individualidade enquanto essência, esse movimento de superação constante frente às dificuldades financeiras e sociopolíticas, todos esses elementos são princípios fundamentais que fazem a diferença no panorama teatral brasileiro e no universo cênico mundial.

\footnotetext{
${ }^{27}$ No dia 7 de abril de 2010 a Comissão de Anistia do Ministério da Justiça do Brasil indenizou o ex-perseguido político José Celso Martinez Corrêa, diretor artístico e presidente da Associação Teatro Oficina Uzyna Uzona, pelos danos físicos, morais e psicoemocionais pelos quais sofreu entre os anos de 1974 (sua prisão e tortura) e 1978 (volta do exílio político) por causa da ditadura militar no Brasil.
} 
Em Os sertões, a autoencenação da própria história do Oficina se dá a partir de fatos históricos que são sensíveis ao corpo-pulsão do grupo, é uma procedência de sua práxis social, política e criadora. Ela foi construída de forma muito racional, premeditada e com muita preocupação estética. É narrada através de cenas que permeiam a história maior - a Guerra de Canudos - e são constituídas de: alusões às peças que fazem parte de seu repertório; ${ }^{28}$ manifestações dos ritos xamânicos, do candomblé e da umbanda, das festas dionisíacas, da fé e das culpas cristãs - bases metafísicas que compõem o imaginário religioso brasileiro; ações e reações políticas um olhar agudo sobre o crescimento da violência mercantil do capital (GSS) mobilizando a arte (Associação Teat(r)o Oficina Uzyna Uzona) como forma de desmascarar os chefes econômicos do poder capitalista. A partir da encenação desse ato político, Os sertões torna visível o invisível, ou seja, se apresenta em sua nudez, como um grupo teatral formado de indivíduos tipicamente divergentes, de seres humanos em trajetórias irregulares, pedaços de histórias que integram outros grupos sociais governados pela dinâmica capitalista, mas, antes de tudo, indivíduos de desagregação, ou melhor dizendo, subversivos a toda essa ordem imposta. Os enganos revelam-se, para o público e para si mesmos, a imprevisibilidade e a capacidade de causar surpresas, alterando não só a função convencional do teatro burguês como também a realidade de sua trajetória na história política de seu país. Eis a magia da peça: ao se revelarem, os a(u)tores de Os sertões tornam visível a verdadeira face dos agentes capitalistas e de toda a violência que existe por detrás dos discursos ideológicos dominantes, fundamentados nos padrões e formalizações sensíveis dessa classe dominante, argumentos legitimados pelas falsas "leis naturais” do desenvolvimento e da civilização, mas que são na verdade uma violência contra a humanidade.

Essa voz intrincada, que des-cobre a realidade, tira a máscara do ser humano e denuncia a hipocrisia dos moralistas, não se apresenta nas cenas como a voz do homem do ressentimento, tal como categoriza Nietzsche em Genealogia da moral, ${ }^{29}$ mas, sim,

\footnotetext{
${ }^{28}$ No decorrer das cinco peças, são citadas as seguintes encenações realizadas pelo grupo: Vento Forte para papagaio subir (José Celso Martinez Corrêa, escrita nos anos 1960 e encenada somente em 2008), Esperando Godot (Becket, 2001), Cacilda! (José Celso, 1998), Para dar um fim ao juízo de Deus (Artaud, 1996), As bacantes (Eurípedes, 1996), Ham-Let (Shakespeare, 1993), Os mistérios gozozos (Oswald de Andrade, 1985), Gracias, Señor (José Celso Martinez Correa, 1972), Roda Viva (Chico Buarque, 1968), O Rei da vela (Oswald de Andrade, 1967.)

29 “O homem do ressentimento não é fraco, nem ingênuo, nem honesto e reto consigo. Sua alma olha de través; ele ama os refúgios, os subterfúgios, os caminhos ocultos, tudo escondido lhe
} 
como a voz do guerreiro forte, do cidadão que resistiu à ditadura militar, do homem que apesar da opressão política que o cerca não se rende à derrota e ao cabresto de um governo ditatorial que criminaliza a liberdade de expressão e de ação democrática. Esse homem forte se redime das mazelas que sofreu e assume o papel de transformador dessa realidade instituída pelos agentes do poder financeiro. Contar a história do Teatro Oficina é, sem sombra de dúvidas, contar a história de José Celso.

Para ilustrar o que acabei de expor em forma de imagens, descreverei apenas mais uma breve cena entre muitas outras que compõem a obra Os sertões. É a abertura da última parte - A Luta II, o desmassacre: o público espera na calçada, onde aparecem, de sobressalto, vários atores de fardas militares e fortemente armados esbravejando pela “Não deposição às armas”. Com voz de comando, o Tenente Pires Ferreira abre caminho entre a multidão e incita o público para o ataque a Canudos/Teatro Oficina:

Eu Tenente Pires Ferreira
Herói de Guerra e desta Feira!
Paulista!
Brado: Abaixo a Monarquia Terrorista!
(apontando o telão)
Vejam que imagens indecentes
usadas neste Teatro Oficina, este antro de Monarquistas doentes!
Dizem ser arte, “Os Sertões”, nessa mentirosa encenação!
Aproveitando-se da nossa derrota na terceira expedição,
pretendem mais, se expandir por todo quarteirão,
nos privando do progresso do Shopping do Minhocão!
Nesta manifestação pelos Humanos Direitos de Propriedade,
Da República agonizante clamemos: às armas povo desta cidade!
Vejam: a República está a perigo. É preciso salvar a República!

Entra a República (Vera Barreto Leite) toda entubada numa cama de UTI, monitorizada por uma equipe médica e a Estátua da Liberdade (Sylvia Prado) passando mal. Dirigem-se ao teatro. O prelúdio se estende em várias cenas na rua impedindo o fluxo do trânsito no horário de pico (geralmente as peças do grupo iniciam-se no fim da tarde ou início da noite dada a extensão de suas horas), até que os soldados mandam todos levantarem as mãos e indicam a entrada do teatro. Nos portões, vasculham bolsas e revistam espectadores, perguntam se somos comunistas ou simpatizantes da esquerda,

agrada como seu mundo, sua segurança, seu bálsamo; ele entende do silêncio, do nãoesquecimento, da espera, do momentâneo apequenamento e da humilhação própria.” (NIETZSHE. Genealogia da moral, p. 30.)

${ }^{30}$ Roteiro da peça A Luta II (Prólogo: Na Rua Jaceguay, no papel de Rua Ouvidor, convocação da população à Guerra contra o Crime Organizado da Monarquia em Canudos e as pretensões expansionistas do Teatro Oficina no quarteirão do Shopping Silvio Santos). 
interrogam alguns e pedem a identidade. A ação faz uma referência ao comando CCC (Comando de Caça aos Comunistas), ordem fundada no governo militar para prender os cidadãos suspeitos de práticas políticas contra o poder do Estado. A mesma força paramilitar que ocupou o Teatro Ruth Escobar em 1968, após a apresentação da peça Roda Viva, deixando o público sair para depois invadir palco e camarins, destruindo tudo o que havia pela frente e espancando os atores e atrizes. Esse episódio foi muitas vezes vivenciado pelo grupo com variações de gravidade, até o exílio de José Celso, em 1974.

Os atores do Oficina transformam, nessas cenas, o Tabu em Totem. Refletem o conjunto de ações próprias do poder autoritário em uma prática ritualística, se redimem dos efeitos desse poder e convertem, contudo, arte em poder de provocação, em poder de transformação. Cria-se, nesse sentido, uma situação cênica que leva o público a sair de seu estado de estagnação, tenta despertar nos observadores uma consciência de seus papéis de atuadores na sociedade, ou seja, parte do micro (indivíduo) para chegar ao macro (coletivo) - da história do grupo para a história política do país, ou vice-versa. E deixa claro que aquilo é teatro, mas que está em ritmo intenso com a vida.

A teatralização dessa posição política representa uma práxis como materialização significante de acontecimentos cênicos. As inferências históricas e de acontecimentos atuais que fazem parte da vida cotidiana das pessoas que ali assistem ${ }^{31}$ são muitas e funcionam como feedbacks para interpretações livres e sensíveis às vivências de cada um. Não levam os espectadores a respostas, mas suscitam perguntas e inúmeros questionamentos. Dentro dessa práxis é possível subverter qualquer forma de poder: as verdades absolutas são pulverizadas; as hierarquias institucionais do Estado, as leis impostas pelo governo e pela ciência política, a moral hipócrita e a ordem pública são desconstruídas. Contudo, Os sertões não cria outras ordens de poder em substituição àquelas desconstruídas em cena, mas introduz o novo e o caos na percepção ordenada e ordenadora do espectador, rompe com o princípio de linearidade ${ }^{32}$ da História, mina o

${ }^{31}$ O que justifica a essência de metamorfose constante do texto espetacular, pois a cada encenação os acontecimentos jornalísticos em pauta são outros e os autores/atuadores da peça atualizam o texto de acordo aos acontecimentos discutidos naquele momento, acontecimentos que giram em torno a assuntos de ordem política, econômica, social e cultural. Inclusive alguns conflitos internos do grupo às vezes são apresentados em breves discursos e retrucados pelos próprios atores ou diretor nas cenas.

${ }^{32}$ Lina Bo Bardi: "Mas o tempo linear é uma invenção do ocidente / o tempo não é linear, / é um maravilhoso / emaranhado onde a qualquer / instante podem ser escolhidos pontos, / e 
consenso de imparcialidade do cidadão comum diante da História e das ciências e mostra que tudo é narrado a partir de um ponto de vista, que por trás dos fatos contados há sempre uma pessoa que se apresenta como mediador dos dados, um sujeito que favorece ou desmerece sempre uma das partes. Por esse motivo, tudo deve ser questionado, tudo deve estar no patamar da dúvida constante.

Nesse caso, Os sertões é uma peça de essência política não por contar um acontecimento político, mas por possibilitar uma abertura do procedimento logocêntrico no qual domina a identificação - a Guerra de Canudos, a luta da arte antropófaga contra o GSS, a história do Brasil e a formação de nossa raça mestiça, a história do grupo Oficina -, em favor de uma prática que não teme nem a interrupção, nem a suspensão da função de denominação do poder pelo poder. Essa tese inclui um paradoxo aparente, como afirma Hans-Thies Lehmann: “O teatro é político na medida em que interrompe e destitui as categorias do político no lugar de colocar novas leis, ainda que elas sejam concebidas com as melhores intenções. ${ }^{\text {33 }}$ Eis o teatro de tese proposto e difundido por Piscator e desenvolvido por Brecht. José Celso dá a sua contribuição para o contínuo desenrolar dessa práxis. Essa sua reflexão pode ser lida em seu diário datado de 1977, Paris: “Aprendemos que os dados cultural e político são um só. Não se os dissocia, nem querendo. Não há ação politicamente revolucionária se formos reacionários culturalmente.»34

A pergunta que este ensaio propõe aos leitores é: Como todo esse movimento de expressão política acontece através da teatralidade da obra Os sertões? Outras perguntas são suscitadas, quando se pensa em teatralidade, principalmente no que diz respeito ao ato de teatralizar no Oficina: Como analisar essa teatralidade numa peça tão estilisticamente marcada pela literariedade, no caso de Os sertões de Euclides da Cunha? Já temos como resposta que esse teatralizar remete à ideia de superação psíquica de uma condição política do grupo vivenciada desde os anos 1960 até a batalha do poder da arte contra as forças do capitalismo (GSS). O sertão nesse caso não é uma metáfora, mas, como afirma Guimarães Rosa e depois José Celso, “o sertão está em

inventadas soluções / sem começo nem fim...” (Citação que está no Programa de A Terra. Teatro Oficina Uzyna Uzona, 2006, p. 11.)

${ }^{33}$ LEHMANN. O teatro pós-dramático, p. 38.

${ }^{34}$ MARTINEZ CORRÊA. Primeiro Ato: cadernos, depoimentos, entrevistas (1958-1974), p. 134. 
toda parte”. ${ }^{35}$

\section{RESUMEN}

El presente ensayo desarrolla una reflexión sobre la lectura que José Celso Martinez Corrêa hizo del personaje Euclides da Cunha y de su obra Os sertões como una expresión de acto político. La pieza está dividida en cinco partes: A Terra, O Homem I, O Homem II, A Lutas I e A Luta II - cada una es presentada en un día y suma un total de casi $30 \mathrm{~h}$ de presentación espectacular. El texto dramatúrgico/espectacular de José Celso es considerado en esta investigación como una lectura/concepción de Os sertões de Euclides da Cunha y, como tal, reproduce todas contradicciones y particularidades teatrales del grupo a lo largo de su trayectoria de más de 50 años de actuación.

\section{PALABRAS-CLAVE}

Teatro Oficina, José Celso Martinez Corrêa, política, arte, identidad cultural

\section{REFERÊNCIAS}

ANDRADE, Oswald de. Manifesto Antropofágico. In: TELES, Gilberto Mendonça. Vanguarda européia e modernismo brasileiro. Rio de Janeiro: Record, 1987.

ARTAUD, Antonin. O teatro e seu duplo. 2. ed. Trad. Teixeira Coelho. São Paulo: Martins Fontes, 1995.

BENJAMIN, Walter. Que é o teatro épico? Um estudo sobre Brecht. In: . Obras Escolhidas. Trad. Sergio Paulo Rouanet. São Paulo: Brasiliense, 1994. v. I.

BRECHT, Bertold. Estudos sobre teatro. Trad. Fiama Paes Brandão. 2 ed. Rio de Janeiro: Nova Fronteira, 2005.

CAMPOS, Augusto e Haroldo de. Panaroma de Finnegans Wake. São Paulo: Perspectiva, 2003.

COHEN, Renato. Work in progress na cena contemporânea. São Paulo: Perspectiva, 2006.

COHEN, Renato. Performance como linguagem. São Paulo: Perspectiva, 2007.

CUNHA, Euclides da. Os sertões (Edição: Leopoldo M. Bernucci). São Paulo: Ateliê, 2002.

DELEUZE, Gilles; GUATTARI, Félix. Mil platôs: capitalismo e esquizofrenia. São Paulo: Ed. 34, 2004. v. 3.

MINISTÉRIO DA EDUCAÇÃO E DA CULTURA. SEC. SERVIÇO NACIONAL DE

\footnotetext{
${ }^{35}$ ROSA. Grande sertão: veredas, p. 24.
} 
TEATRO - DIONYSOS - TEATRO OFICINA, n. 26, jan. 1982.

FREUD, Sigmund. Totem e tabu. São Paulo: Imago, 1972.

GROTOWSKI, JERZY. Teatro laboratório de Jarzy Grotowski 1953 - 1969. Trad. Berenice Raulino. São Paulo: Perspectiva, 2007.

LEHMANN, Hans-Thies. O teatro pós-dramático. Trad. Pedro Süssekind. São Paulo: Cosac Naify, 2009.

MARTINEZ CORRÊA, José Celso. Primeiro Ato: cadernos, depoimentos, entrevistas (1958-1974). Org. Ana Helena Camargo de Staal. São Paulo: Ed. 34, 1998.

MOSTAÇO, Edécio; SAADI, Fátima. Entrevista com Zé Celso: “O anarquista coroado”. Revista Folhetim: Teatro do pequeno Gesto, n. 12, p. 149, jan./mar. 2002.

NIETZSCHE, Friedrich. Genealogia da moral. São Paulo: Companhia das Letras, 2007. PAVIS, Patrice. A análise dos espetáculos. São Paulo: Perspectiva, 2005.

REVISTA FOLHETIM: Teatro do Pequeno Gesto, n. 12, p. 125, jan.-/mar. 2002.

ROSA, João Guimarães. Grande sertão: veredas. Rio de Janeiro: Nova Fronteira, 2008.

SILVA, Armando Sérgio da. Oficina: do teatro ao te-ato. São Paulo. Perspectiva, 1981.

TEATRO OFICINA. Os Sertões / A Terra (programa da peça). São Paulo: Teatro oficina: 2006.

TEATRO OFICINA. Os Sertões / O Homem I: o pré-homem à revolta (programa da peça). São Paulo: Teatro Oficina: 2006.

TEATRO OFICINA. Os Sertões / O Homem II: da revolta ao trans-homem (programa da peça). São Paulo: Teatro Oficina: 2006.

TEATRO OFICINA. Os Sertões / A Luta: primeira parte - 1a, 2a. e 3a. expedições + Rua do Ouvidor (programa da peça). São Paulo: Teatro Oficina: 2006.

TEATRO OFICINA. Os Sertões / A Luta: segunda parte - O desmassacre (programa da peça). São Paulo: Teatro Oficina: 2006. 